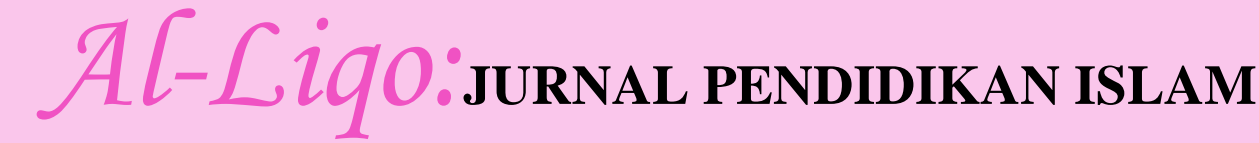 \\ P-ISSN: 2461-033X | E-ISSN: 2715-4556
}

\section{Kehidupan Sakinah Dalam Perspektif Pendidikan Islam}

\author{
${ }^{*}$ Seriyanti Siagian ${ }^{1}$,M. Ilyas ${ }^{2}$ Hasnawati $^{3}$ \\ ${ }^{1}$ STAI Auliaurrasyidin Tembilahan, Indragiri Hilir, Riau (seri.yanti@stai-tbh.ac.id) \\ ${ }^{2}$ STAI Auliaurrasyidin Tembilahan, Indragiri Hilir, Riau, (muhammad.ilyas@stai-tbh.ac.id) \\ ${ }^{3}$ STAI Auliaurrasyidin Tembilahan, Indragiri Hilir, Riau (hasnawati@stai-tbh.ac.id)
}

\begin{abstract}
The formulation of the problem in writing this journal is how to live a sakinah life in the perspective of the Qur'an, what are the requirements for achieving a sakinah life and what are the signs that a person gets (reaches) a sakinah life. While the purpose of this paper is to find out the formulation of the problem above. This writing methodology is qualitative with the type of literature research, using inductive and deductive thinking. The findings in this paper explain that the sakinah life in the perspective of the Qur'an according to the letter at-taubah verse 6 we should not be proud of the quantity we have without being accompanied by quality, while the letter attaubah verse 40 explains that we should not be afraid/ afraid of the stress of others, even though we have to struggle very tiring, as long as we believe that Allah SWT is always with us, then we will achieve sakinah life. There are two conditions for achieving sakinah globally, namely, First, a person must empty his heart (heart) of all despicable traits (inner immorality), Second, a person must prioritize the qualities of praise/commendable morals (inward obedience).
\end{abstract}

Keywords: Sakinah, Perspective of the Qur'an

\begin{abstract}
Abstrak
Rumusan masalah dalam penulisan jurnal ini adalah bagaimana kehidupan sakinah dalam perspektif Al-Qur'an, apa syarat-syarat menggapai kehidupan sakinah dan apa tanda-tanda seseorang mendapat (menggaapai) kehidupan sakinah. Sedangkan tujuan dalam penulisan ini adalah untuk mengetahui rumusan masalah di atas. Metodologi penulisan ini bersifat kualitatif dengan jenis penelitian pustaka, dengan menggunakan cara berpikir induktif dan deduktif. Hasil temuan dalam penulisan ini menjelaskan bahwa kehidupan sakinah dalam perspektif Al-Qur'an menurut surat at-taubah ayat 6 kita tidak boleh berbangga terhadap kuantitas yang kita miliki tanpa disertai kualitas, sedangkan surat at-taubah ayat 40 menjelaskan bahwa kita tidak boleh takut/gentar terhadap cekaman orang lain, walaupun kita harus berjuang yang sangat melelahkan, asalkan kita meyakini bahwa Allah SWT selalu bersama kita, maka kehidupan sakinah akan kita gapai. Syarat-syarat menggapai sakinah secara global ada dua yaitu, Pertama, Seseorang harus mengosongkan hatinya (kalbunya) dari segala sifat-sifat tercela (maksiat bathin), Kedua, Seseorang harus mengedepankan sifat-sifat kepujian/akhlak terpuji (ta'at bathin).
\end{abstract}

Kata Kunci: Sakinah, Perspektif Al-Qur'an

Cara Mensitasi Artikel:(APA 6)

Siagian, S. Y., Ilyas, M., \& Hanawati, H. (2021). Kehidupan Sakinah dalam Perspektif Pendidikan Islam. Al-Liqo: Jurnal Pendidikan Islam, 6(2), 96-107. https://doi.org/10.46963/alliqo.v6i2.444.

*Corresponding Author:

seri.yanti@stai-tbh.ac.id

Editorial Address:KampusParitEnam, STAI

Auliaurrasyidin Tembilahan.Jl. Gerilya No. 12

Tembilahan Barat, Riau Indonesia 29213.
HistoriArtikel:

$\begin{array}{ll}\text { Diterima } & : 11 / 12 / 2021 \\ \text { Direvisi } & :- \\ \text { Diterbitkan } & : 31 / 12 / 2021\end{array}$

DOI:https://doi.org/10.46963/alliqo.v6i2.444 
Kehidupan Sakinah Dalam Perspektif Pendidikan Islam

\section{PENDAHULUAN}

Kehidupan sakinah merupakan dambaan setiap orang dalam membangun hidup khususnya berumah tangga, yang mana aggota sebuah rumah tangga pada umumnya terdiri dari ibu, bapak dan sejumlah anggota keluarga yang lain. Namun ternyata tidak setiap orang yang berumahtangga dapat menggapainya. Bahkan tidak sedikit kita jumpai keluarga yang penuh konflik dimana anggota keluarga tidak betah tinggal di dalamnya dikarenakan akhlak tercela menghiasi diri mereka.oleh karenanya ketiga macam penghuni inilah yang akan mewarnai corak rumah tangga dan juga akan mewarnai hidup masyarakat yang lebih luas. (M.K. Chizbulloh, 1982: 67)

Sejarah penjang Islam mencatat bahwa akhlak mulia yang tertanam dalam pribadi mu'min yang diterapkan dalam kehidupan masyarakat khususnya dalam rumah tangga muslim akan mampu menumbuhkan dan menciptakan kekuaatan yang sangat dahsyatjuga sangat berpengaruh dalam mewujudkan sifat-sifat sosial yang terpuji dalam masyarakat. (Muhammad Farhad dkk, 2005: 102).

Allah SWT., menjanjikan kepada seseorang yang beriman, bahwa nantinya mereka dapat berkumpul dengan keluarganya, sebagainmana harapan yang senantiasa didambakan oleh manusia pada umumnya untuk selalu berkumpul dengan anggota keluarganya dimanapun dan kapanpun waktunya. Sebagaimana halnya suatu keluarga menginginkan adanya kebahagiaan dalam keluarga. (Imam Jalaluddin Al-Mahalli \& Jalaluddin As-Suyuti, 2003: 941. Cet. Ke-1).

Sebagaimana firman Allah SWT:

Artinya:" Dan orang-orang yang beriman, dan yang anak cucu mereka mengikuti mereka dalam keimanan, Kami hubungkan anak cucu mereka dengan mereka, dan Kami tiada mengurangi sedikit pun dari pahala amal mereka. Tiap-tiap manusia terikat dengan apa yang dikerjakannya”. (Q.S. Ath-Thuur:21)

Oleh karenanya, perlu dipahami bahwa ajaran agama Islam,penuh dengan hukum yang berkaitan dengan urusan membina rumah tangga dan masyarakat pada umumnya, yang kesemuanya itu bertujuan kearah terciptanya masyarakat yang penuh dengan sakinah (ketenangan).

Lihat Sakinah dalam firman Allah SWT surat Al-Rum ayat 21. 


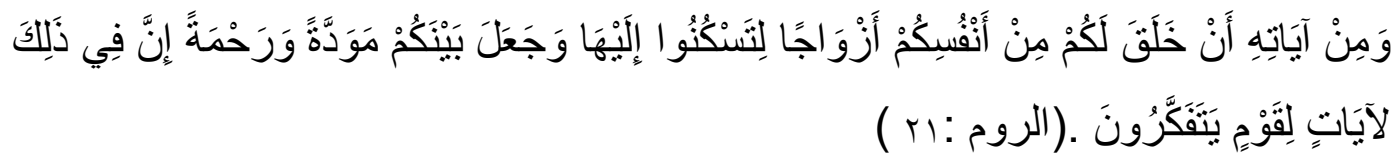

Artinya"Dan di antara tanda-tanda kekuasaan-Nya ialah Dia menciptakan untukmu istri-istri dari jenismu sendiri, supaya kamu cenderung dan merasa tenteram (sakinah) kepadanya, dan dijadikan-Nya di antaramu rasa kasih dan sayang. Sesungguhnya pada yang demikian itu benarbenar terdapat tanda-tanda bagi kaum yang berpikir".(Q.S.Ar-Rum:21).

\section{METODE}

Tulisan ini merupakan penelitian pustaka. Penelitian ini merupakan penelitian deskriptif dengan menggunakan pendekatan kualitatif. Penelitian deskriptif adalah penelitian yang berusaha mendeskripsikan suatu gejala, peristiwa, kejadian yang terjadi pada saat sekarang. Dengan kata lain, penelitian deskriptif adalah penelitian yang mengambil masalah atau memusatkan perhatian kepada masalah-masalah aktual sebagaimana adanya pada saat penelitian dilaksanakan. (Nana Sudjana dan Ibrahim, 2001: 64). Penelitian ini menggambarkan masalah-masalah yang terjadi pada setiap orang khususnya yang sudah berkeluarga dalam menciptakan kehidupan yang sejahtera. Sumber Data dua sumber, yaitu: Sumber Primer dan Sumber Sekunder.

Ahmad Sunarto. (1996). Membersihkan Hati dari Akhlaq yang Tercela. Surabaya: Pustaka Amani. cet. I

Imam Jalaluddin Al-Mahalli \& Jalaluddin As-Suyuti. (2003). Tafsir Jalalain. Bandung: Sinar Baru Algensindo.

M.Quraish Shihab. (tt). Secercah Cahaya Ilahi : Hidup Bersama Al-Qur'an. Muhammad Sarni (1973). Ilmu Tasawwuf. Banjarmasin: Murni.

Muhammad Farhad dkk. (2005). Membangun Moralitas Bangsa. Surabaya: Penerbit Amalia.

M.K. Chizbulloh. (1982). Khutbah-Khutbah Pilihan. Jakarta: Pustaka Amani. 
Kehidupan Sakinah Dalam Perspektif Pendidikan Islam

\section{HASIL DAN PEMBAHASAN}

Sakinah dalam bahasa arab sakana-yaskunu-saknan atau sukunan yang berarti tenang atau diam. (Mahmud Yunus, 1989: 174). Haruka-yahruku-harakan atau harakatan yang berarti bergerak. Rumah dinamai maskanun sedangkan jamaknya masakinun. Karena ia adalah nama tempat untuk meraih ketenangan setelah sebelumnya penghuninya bergerak atau mengalami keguncangan bathin di luar rumah, karena menghadapi berbagai persoalan hidup.

Menurut Ali ibn Muhammad al-Jurjani, sakinah adalah ketenangan dalam hati pada saat datang sesuatu yang tak terduga, dibarengi cahaya dalam hati yang memberi ketenangan pada yang menyaksikannya dan merupakan pokok keyakinan berdasarkan penglihatan ('ainul yaqin). (Hasan Muarif Ambary at all (ed.), 1999: 202. Jilid IV).

Menurut Al-Raghib al-Isfahani, seorang fakar leksikografi al-Qur'an mengartikan sakinah adalah tidak ada rasa gentar dalam menghadapi segala sesuatu.

\section{Kehidupan Sakinah Dalam Perspektif Pendidikan Islam}

Al-Qur'an banyak menyebutkan kata sakinah antara lain. Sakinah dalam firman Allah SWT surat Al-Baqarah ayat 248.

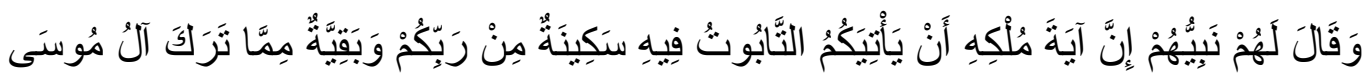

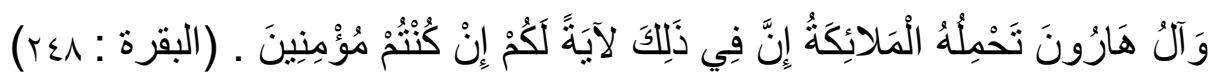

Artinya"Dan Nabi mereka mengatakan kepada mereka: "Sesungguhnya tanda ia akan menjadi raja, ialah kembalinya tabut kepadamu, di dalamnya terdapat ketenangan (sakinah) dari Tuhanmu dan sisa dari peninggalan keluarga Musa dan keluarga Harun; tabut itu dibawa oleh Malaikat. Sesungguhnya pada yang demikian itu terdapat tanda bagimu, jika kamu orang yang beriman".'(Q.S. Al-Baqarah : 248)

Ayat di atas berkaitan dengan cerita tentang Samuel dan Bani Israil. Diceritakan, Samuel memberitahu Bani Israil bahwa Allah menunjuk Talut menjadi raja mereka. Bani Israil pada mulanya menolak penunjukan itu karena Talut bukan orang kaya. Namun, setelah Samuel menjelaskan kelebihan ilmu dan kekuatan fisik Talut sebagai alasan penunjukannya sebagai raja, mereka akhirnya 
menerima. Pilihan Allah itu dibuktikan dengan datangnya tabut (kotak suci) yang berisi peninggalan Nabi Musa dan Nabi Harun yang dibawa oleh malaikat. Pernyataan"sakinah dari Tuhanmu terdapat pada tabut itu" yang terdapat dalam ayat alat tersebut, menurut sebagian mufassir, disebabkan oleh penghormatan Bani Israil pada tabut sebagai kotak penyimpanan taurat. Diceritakan bahwa Nabi Musa bila berperang selalu membawa tabut itu sehingga pengikutnya merasa tenang dan tidak lari dari medan perang. (Hasan Muarif Ambary at all (ed.), 1999: 201. Jilid IV).

Sakinah dalam firman Allah SWT surat Al-Taubah ayat 26.

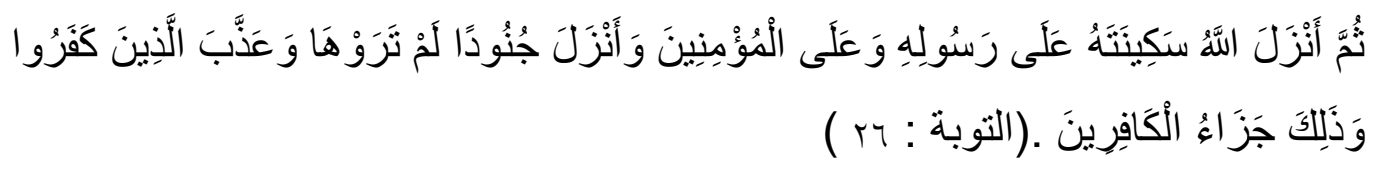

Artinya"Kemudian Allah menurunkan ketenangan (sakinah) kepada Rasul-Nya dan kepada orang-orang yang beriman, dan Allah menurunkan bala tentara yang kamu tiada melihatnya, dan Allah menimpakan bencana kepada orang-orang yang kafir, dan demikianlah pembalasan kepada orang-orang yang kafir”. (Q.S. At-Taubah : 26)

Ayat di atas menceritakan tentang Parang Hunain dimasa Nabi Muhammad SAW. Ketika itu, sebagian pasukan berbangga dengan kuantitas mereka."Kali ini kita tidak terkalahkan" ucapan salah seorang di antara mereka yang dibenarkan oleh yang lain. Akan tetapi, kenyataannya tidak demikian. Pasukan yang berjumlah tiga puluh ribu, atau dua puluh ribu orang (dalam riwayat lain), menjadi kucar-kacir akibat serbuan dahsyat dari pihak musuh, meskipun jumlah mereka lebih sedikit, sehingga hanya tersisa tidak lebih dari tiga ratus orang yang bertahan. Disaat genting seperti itu, Allah menurunkan sakinah-Nya kepada Rasulullah dan orang-orang beriman dan menurunkan balatentara malaikat yang tidak terlihat untuk mengalahkan pasukan musuh (kafir). (M.Quraish Shihab, tt : $133-134$

Sakinah dalam firman Allah SWT surat Al-Taubah ayat 40.

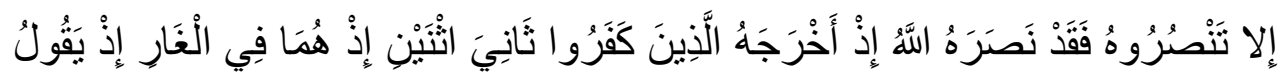

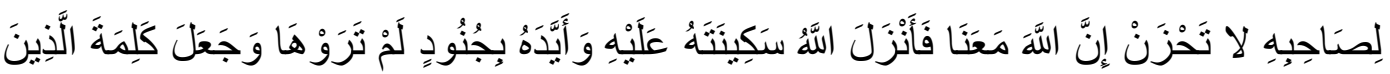

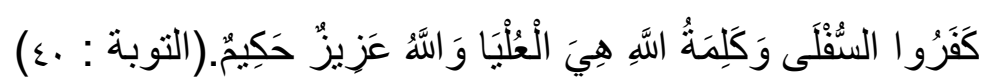


Kehidupan Sakinah Dalam Perspektif Pendidikan Islam

Artinya"Jikalau kamu tidak menolongnya (Muhammad) maka sesungguhnya Allah telah menolongnya (yaitu) ketika orang-orang kafir (musyrikin Mekah) mengeluarkannya (dari Mekah) sedang dia salah seorang dari dua orang ketika keduanya berada dalam gua, di waktu dia berkata kepada temannya: "Janganlah kamu berduka cita, sesungguhnya Allah beserta kita." Maka Allah menurunkan ketenangan (sakinah)-Nya kepada (Muhammad) dan membantunya dengan tentara yang kamu tidak melihatnya, dan Allah menjadikan seruan orang-orang kafir itulah yang rendah. Dan kalimat Allah itulah yang tinggi. Allah Maha Perkasa lagi Maha Bijaksana”. (Q.S. At-Taubah : 40)

Ayat di atas menceritakan tentang perjanjian hijrah Rasulullah SAW. Itu cukup jauh dan sangat melelahkan, bahkan mencekam, apalagi kelompok kaum musyrik Mekah yang telah sepakat untuk membunuh beliau telah berada dimulut gua tsur, tempat mereka bersembunyi sementara. Abu Bakar, ketika itu merasa takut dan gemetar. Dia sangat khawatir persembunyian mereka diketahui kaum musyrik yang mengejar mereka. Setiap orang wajar demikian, apalagi jika mengingat bahwa bila Rasulullah SAW. Terbunuh, ajaran Islam tidak akan tegak. Sebaliknya, Rasulullah sangat tenang, suatu ketenangan yang menjadikan beliau tidak takut menghadapi masa depan dan tidak pula bersedih mengingat masa lalu, karena waktu itu telah memperoleh anugrah sakinah dari Allah SWT. Beliau kemudian menenangkan Abu Bakar dengan mengatakan "jangan berduka cita/takut dan bersedih sesungguhnya Allah beserta kita”.

Sakinah dalam firman Allah SWT surat Al-Fath ayat 4.

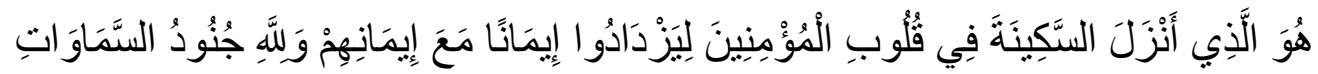

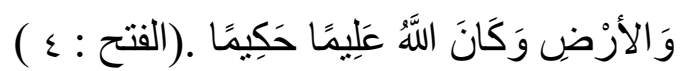

Artinya"Dia-lah yang telah menurunkan ketenangan (sakinah) ke dalam hati orang-orang mukmin supaya keimanan mereka bertambah di samping keimanan mereka (yang telah ada). Dan kepunyaan Allah-lah tentara langit dan bumi dan adalah Allah Maha Mengetahui lagi Maha Bijaksana”. (Q.S. Al-Fath:4)

Sakinah dalam firman Allah SWT surat Al-Fath ayat 18.

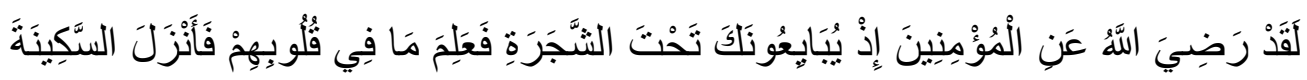

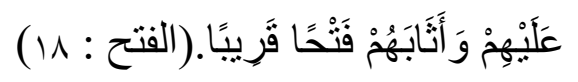


Artinya"Sesungguhnya Allah telah rida terhadap orang-orang mukmin ketika mereka berjanji setia kepadamu di bawah pohon, maka Allah mengetahui apa yang ada dalam hati mereka lalu menurunkan ketenangan (sakinah) atas mereka dengan memberi balasan kepada mereka dengan kemenangan yang dekat (waktunya)'.(Q.S.Al-Fath:18)

Sakinah dalam firman Allah SWT surat Al-Fath ayat 26.

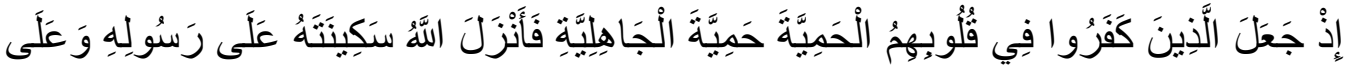

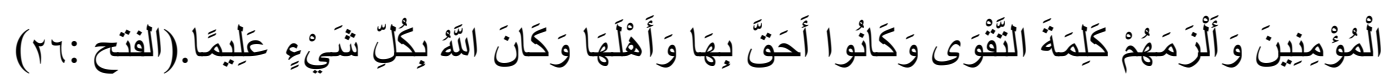

Artinya"Ketika orang-orang kafir menanamkan dalam hati mereka kesombongan (yaitu) kesombongan jahiliah lalu Allah menurunkan ketenangan (sakinah) kepada Rasul-Nya, dan kepada orang-orang mukmin dan Allah mewajibkan kepada mereka kalimat takwa dan adalah mereka berhak dengan kalimat takwa itu dan patut memilikinya. Dan adalah Allah Maha Mengetahui segala sesuatu”. (Q.S.Al-Fath:26)

Sakinah dalam firman Allah SWT surat Al-Araf ayat 189.

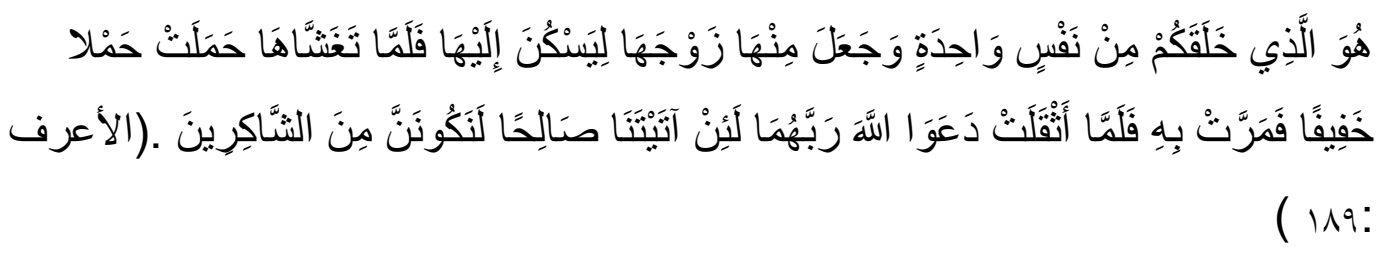

Artinya"Dialah Yang menciptakan kamu dari diri yang satu dan daripadanya Dia menciptakan istrinya, agar dia merasa senang (sakinah) kepadanya. Maka setelah dicampurinya, istrinya itu mengandung kandungan yang ringan, dan teruslah dia merasa ringan (beberapa waktu). Kemudian tatkala dia merasa berat, keduanya (suami istri) bermohon kepada Allah, Tuhannya seraya berkata: "Sesungguhnya jika Engkau memberi kami anak yang sempurna, tentulah kami termasuk orang-orang yang bersyukur".(Q.S.Al- 'Araf:189)

\section{Syarat Menggapai Kehidupan Sakinah}

Sakinah merupakan anugrah Allah SWT. Tidak datang begitu saja, tetapi ada syaratnya. Hati (kalbu) orang yang akan menerimanya harus disiapkan dengan kesabaran dan ketaqwaan. Jika segala persyaratannya terpenuhi, sakinah baru diturunkan Allah SWT. Ke hati (kalbu)orang tersebut, demikian ayat-ayat di atas mengungkapkannya.

Sakinah baru diperoleh seseorang setelah melalui beberapa fase. Pertama, Seseorang harus mengosongkan hatinya (kalbunya) dari segala sifat-sifat 
Kehidupan Sakinah Dalam Perspektif Pendidikan Islam

tercela (maksiat bathin). Imam Al-Ghazali menyebutkan dalam kitab Arba'in fiUshuluddin, yang tertulis dalam kitab "Ilmu Tasawwuf” karya Moh. Sarni, ada 10 (sepuluh) perkara sifat-sifat tercela/akhlak tercela (maksiat bathin yang dikerjakan oleh hati). (Muhammad Sarni,1973: 11). yaitu : (1) Syarhul Tha'am artinya terlalu banyak makan atau makan melampaui batas yang dikendalikan oleh hawa nafsu karena itu termasuk sifat binatang yang tidak berakal. (2) Syarhul Kalam artinya terlalu banyak berbicara yang tidak berfaedah. (3)Ghadab artinya pemarah yang didasari oleh hawa nafsu yang tidak dibenarkan oleh syara'. (4)Hasad artinya dengki maksudnya menghendaki hilangnya nikmat orang lain. (5)Bukhil artinya kikir karena sangat sayang kepada harta. (6)Hubbud Al-jah artinya mencintai kemegahan atau pangkat kerena dengan itu dia tidak segan berdusta. (7)Hubbud Ad-dunnya artinya mencintai segala kesenangan dan kelezatan dunia yang tidak yang tidak dibolehkan dalam agama. (8)Takabbur artinya sombong atau merasa dirinya lebih besar dari orang lain. Seperti lebih ilmu, lebih kaya, lebih mulia dsb. (9)Ujub artinya perasaan besar yang timbul pada perasaan hati seseorang. Ujub ini lebih halus dari pada sombong. (10) Riya artinya memperlihatkan amal kebaikan kepada manusia supaya mereka memuji kepadanya. Riya ini dinamakan oleh Nabi juga sebagai Syirik Asghar (kecil)., Ahmad Sunarto, 1996: 3-137). Kedua, seseorang harus mengedepankan sifat-sifat kepujian/akhlak terpuji (ta'at bathin). (Ahmad Sunarto,1987: 25).

Imam Al-Ghazali menyebutkan dalam kitab Arba'in fi-Ushuluddin, yang tertulis dalam kitab "Ilmu Tasawwuf" karya Moh. Sarni, ada 10 (sepuluh) perkara ta'at bathin (sifat kepujian yang dikerjakan oleh hati) yaitu : (1) Taubat, (2) Takut, (3) Zuhud, (4) Sabar, (5) Syukur, (6) Ikhlas, (7) Tawakkal, (8) Mahabbah, (9) Ridha, (10) Zikrul Maut,. (Muhammad Sarni,1973: 23). Untuk jelasnya akan diterangkan secara singkat, yaitu :

1) Taubat, artinya berhenti mengerjakan maksiat dengan segala syarat-syaratnya.

Diantara syarat-syarat orang yang bertaubat hendaklah mencukupkan tiga syarat. adalah : (a) berhenti dari mengerjakan maksiat yang telah dikerjakan itu. (b) menyesal atas perbuatannya itu. (c) bercita-cita bahwa ia tidak akan kembali lagi mengerjakannya. 
2) Takut, (takut kepada Allah), artinya kecut hati dan kekhawatiran akan datangnya sesuatu yang tidak diingini oleh tiap-tiap manusia.

3) Zuhud, artinya berpaling dari dunia dan perhiasannya dan mengambil sekedar hajat (keperluan) saja. Lawannya "Hubbud dunnya wama fiiha" (mencintai dunia dan segala isinya.

4) Sabar, artinya menahan diri dari marah dan gelisah atas sesuatu yang tidak sangkanya. Sabar itu terbagi tiga, yaitu : (1) sabar atas mengerjakan taat. (2) sabar dari meninggalkan maksiat. (3) sabar ketika kedatangan bencana dan musibah.

5) Syukur, artinya mempergunakan segala nikmat pemberian Tuhan yang ada pada kita kepada sesuatu yang diridlainya.

6) Ikhlas, artinya bersih niat dalam beramal. Yang maksudnya, semata-mata karena Allah bukan karena yang lainnya. Ikhlas lawannya Riya dan Ujub.

7) Tawakkal, artinya percaya dan yakin bahwa Allah itulah yang menjamin atas rezki dan kehidupan tiap-tiap makhluk yang telah dijadikannya dan tidak membedakan antara ketika keadaan berada atau ketika dalam kemiskinan.

8) Mahabbah, artinya telah kuat tawakkal seseorang kepada Allah.

9) Ridha, artinya menerima dengan senang hati apa-apa yang telah dilakukan Tuhan (pada kita), Qada' dan Qadar.

10) Zikrul Maut, artinya mengingat mati,ini adalah yang terakhir dari sifat kepujian dan taat bathin yang sepuluh perkara. Karena tiap-tiap diri yang bernyawa itu akan merasakan mati.

\section{Tanda-Tanda Seseorang Mendapat (Menggapai) Sakinah}

1. Tanda bahwa seseorang telah mendapat sakinah adalah orang-orang yang berjalan di muka bumi dengan rendah hati, dan mengucapkan kata-kata yang mengandung keselamatan.

Firman Allah SWT surat Al-Furqan ayat 63.

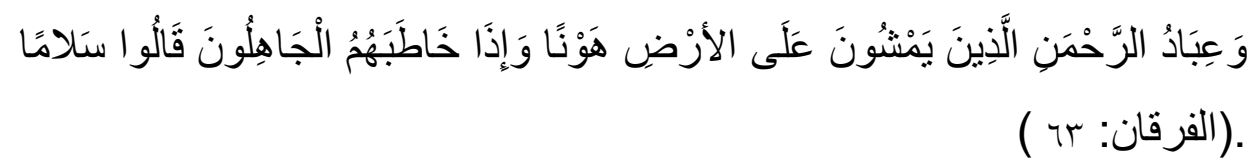


Kehidupan Sakinah Dalam Perspektif Pendidikan Islam

Artinya"Dan hamba-hamba Tuhan Yang Maha Penyayang itu (ialah) orangorang yang berjalan di atas bumi dengan rendah hati dan apabila orang-orang jahil menyapa mereka, mereka mengucapkan kata-kata yang baik”.(Q.S.Al-Furqan:63)

Sakinah bukan sekedar terlihat pada ketenangan lahir yang tercermin pada kecerahan air muka, sebab, yang demikian itu muncul akibat ketidak tahuan atau kebodohan. Akan tetapi, sakinah terlihat pada kecerahan air muka yang disertai dengan kelapangan dada, perkataan dan akhlak yang halus, yang dilahirkan oleh ketenangan bathin akibat menyatunya pemahaman dan kesucian hati, serta bergabungnya kejelasan pandangan dengan tekad yang kuat.Seseorang yang telah mengusasi sakinah didalamnya akan tercipta seserasian dan keharmonisan antara unsur yang berbeda, bahkan yang bertentangan di dalam jiwanya. Itulah sifat-sifat yang dimiliki oleh 'ibad AlRahman (hamba-hamba Allah Yang Maha Pengasih, yang dijelaskan Allah SWT. Dalam firman-Nya tersebut, yakni memiliki sikap lapang dada, tabah dan tenang serta selalu memilih kata-kata yang lemah lembut, menghindari katkata yang menimbulkan keributandalam menghadapi segala situasi.

2. Tanda bahwa seseorang telah mendapat sakinah adalah orang-orang yang bersedia mendahulukan kepentingan orang lain di atas kepentingan pribadinya, walaupun dia sendiri berada dalam kesulitan.

Firman Allah SWT surat Al-Hasyr ayat 9.

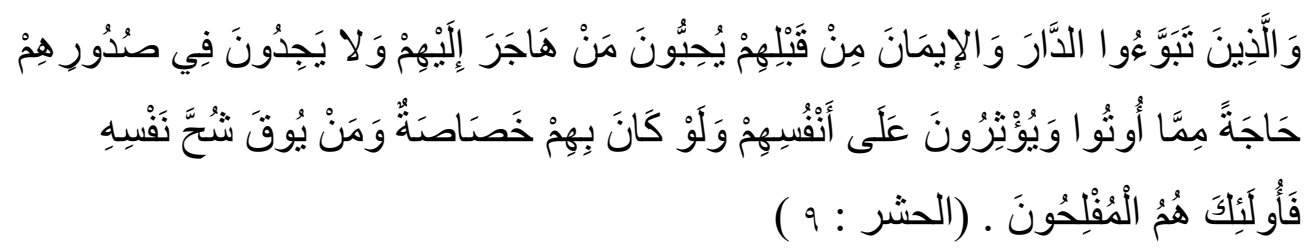

Artinya"Dan orang-orang yang telah menempati Kota Madinah dan telah beriman (Ansar) sebelum (kedatangan) mereka (Muhajirin), mereka mencintai orang yang berhijrah kepada mereka. Dan mereka tiada menaruh keinginan dalam hati mereka terhadap apa-apa yang diberikan kepada mereka (orang Muhajirin); dan mereka mengutamakan (orang-orang Muhajirin), atas diri mereka sendiri. Sekalipun mereka memerlukan (apa yang mereka berikan itu). Dan 
siapa yang dipelihara dari kekikiran dirinya, mereka itulah orangorang yang beruntung".(Q.S.Al-Hasyr:9)

\section{KESIMPULAN}

Sakinah (ketenangan) itu merupakan barang yang sangat langka dan mahal harganya, dan untuk memperolehnya perlu mempersiapkan diri serta perjuangan yang sangat berat, dengan membuang jauh-jauh segala perbuatan atau akhlak tercela (penyakit hati)seperti: Syarhul Tha'am, Syarhul Kalam, Ghadab, Hasad, Bukhil, Hubbud Al-jah, Hubbud Ad-dunnya d, Takabbur, ujub, Riya. Sebaliknya selalu berusaha menghiasi diri dengan perbuatan atau akhlak terpuji (sifat kepujian) seperti: Taubat, Takut, Zuhud, Sabar, Syukur, Ikhlas, Tawakkal, Mahabbah, Ridha, Zikrul Maut. Karena itu hanya di peroleh hasil bagi orangorang tertentu saja, yang penuh dengan kesungguhan dalam memperjuangkannya. Tanda bahwa seseorang telah mendapat sakinah adalah orang-orang yang berjalan di muka bumi dengan rendah hati, dan mengucapkan kata-kata yang mengandung keselamatan dan juga tanda bahwa seseorang telah mendapat sakinah adalah orang-orang yang bersedia mendahulukan kepentingan orang lain di atas kepentingan pribadinya, walaupun dia sendiri berada dalam kesulitan. Sudahkah kita berusaha memperjuangkannya dengan penuh kesungguhan.

\section{REFERENSI}

Amatullah Amstrong. (1995). Sufi Terminology (Al-Qamus al-Sufi). Malaysia: The Mystical Language of Islam, A,S. Noordeen.

Ahmad Sunarto. (1996). Membersihkan Hati dari Akhlaq yang Tercela. Surabaya: Pustaka Amani. cet. I (1987). Pembina Iman dan Akhlaq. Surabaya : Mutiara Ilmu.

Hasan Muarif Ambary at all (ed.). (1999). Ensiklopedi Islam. Jakarta: Ichtiar Baru Van hoeve, Jilid IV.

M.K. Chizbulloh. (1982). Khutbah-Khutbah Pilihan. Jakarta: Pustaka Amani. 
Kehidupan Sakinah Dalam Perspektif Pendidikan Islam

Imam Jalaluddin Al-Mahalli \& Jalaluddin As-Suyuti. (2003). Tafsir Jalalain. Bandung: Sinar Baru Algensindo.

Muhammad Farhad dkk. (2005). Membangun Moralitas Bangsa. Surabaya: Penerbit Amalia.

Mahmud Yunus. (1989). Kamus Arab Indonesia. Jakarta: Penerbit Hidakarya Agung.

M.Quraish Shihab. (tt). Secercah Cahaya Ilahi : Hidup Bersama Al-Qur'an.

Muhammad Sarni (1973). Ilmu Tasawwuf. Banjarmasin: Murni. 